Aldo Torres

\title{
El gran ausente
}

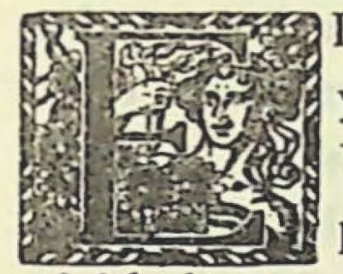

RA VICENTE HUIDOBRO de estatura más bien baja y rostro agudo; de un mirar inquieto, pero penetrante. Vestía con natural sentido del color, de los tonos y las tricidades, no obstante aflorar en él, a veces, el gesto inesperado, la pirueta imprevista. Lo extraordinario se manifestaba en su poesía, en sus manifiestos y polémicas, en sus novelas. Su espíritu especial fosforescía en todo. De buena gana, la ornitología hubiese sacrificado al gorrión como símbolo suyo.

Nuestro contacto con el poeta no fue sino esporádico: saludos callejeros, frases de rigor en un café del centro de Santiago, y un solo encuentro prolongado en su casa de campo, en Cartagena. Acuden primeramente a la memoria la cortesía, la fineza del trato: Es la imagen de su trascendencia personal que aún recordamos, bajo benigna noche de otoño, mientras los contertulios discutían, dentro de la casa, en medio de frecuentes libaciones del rico vino familiar. Había ciertos argentinos que desquiciaban a Eduardo Molina, sobre todo cuando uno de ellos repetía y repetía su golpeante estribillo:

-Pero, che, si esos son problemas espirituales completamente superados.

Nada registramos de la conversación aquélla, salvo la llaneza siempre pareja y la extraña discreción de nuestro amigo si uno lo remitía a las intimidades de la vida literaria de Chile, 
Un día del 50 o del 51 reúnense, en Santiago, un miembro del servicio de Relaciones Exteriores, el señor Suárez (no recordamos su nombre completo) y dos poetas, Daniel de la Vega y Juan Guzmán Cruchaga, viejos amigos de Huidobro. Se proponen visitar su tumba, emplazada en un punto de la heredad campesina del poeta, quien yace de frente al Océano Pacífico, solitario segador de crepúsculos.

Viajan en tren, haciendo recuerdos comunes a los tres y al gran ausente de la vida, mas no de la poesía.

Desde la misma estación de Cartagena emprenden la marcha hacia donde el acendrado lírico de Altazor duerme la combatida eternidad del mar y de la tierra. Siguen silenciosos el camino, duro y áspero cinturón de los cerros costeños. Sus pasos son lentos, acaso entorpecidos por una mezcla de melancolía y de cansancio.

A cierto grado del sendero, sin decir nada y sobre andando, el señor Suárez se inclina, recoge una pequeña piedra, que pone en una de las carteras laterales de su paletó, y continúa, terciando, luego, en la conversación o contemplando el ceñudo semblante del paisaje. Otro trecho, y vuelve a inclinarse para recoger una nueva pedrezuela que deposita en la otra cartera de su paletó.

De pronto arriban al sitio deseado, donde las propias palabras del poeta verifican el asombro de la muerte:

Aqui yace Altazor azor fulminado por la altura Aqui yace Vicente antipoeta y mago.

El señor Suárez rodea el sepulcro. Va a uno de sus extremos; extrae el pedrusco de su derecha; se inclina, como iniciando un rito, y lo hace encajar, perfectamente, en un hueco al ras del suelo. En seguida, siempre mudo, llega al otro extremo, echa mano de la segunda pedrezuela, ajustándola, también perfectamente, en otro hueco. El ritual se ha cumplido. 
-Nunca me hubiera imaginado que los ratones hicieran nido en la tumba de Vicente...

Fue el dolorido comentario de Juan Guzmán Cruchaga, al poner término al relato de cuya versión somos responsables. Nos informó, sí, a continuación, de que, por aquel entonces, el señor Suárez recién regresaba al país después de muchos años de permanencia en Egipto.

¿Qué relación querría insinuar Guzmán Cruchaga entre la circunstancia antedicha y el hecho tan raro que aquí rescatamos del olvido? ¿A qué mandato obedecía todo?

A manera de sonriente desafío, la esfinge huidobriana de la poesía nos advierte:

Aquí comienza el campo inexplorado. 